\title{
Sobre la afectividad de la racionalidad poética en el pensamiento de María Zambrano
}

\author{
About the poetic rationality's emotions \\ on the Maria Zambrano's thought
}

\author{
Humberto ORTIZ BUITRAGO \\ Universidad Central de Venezuela
}

Recibido: 21/01/2010

Aceptado: 18/04/2011

\section{Resumen}

Se revisan aquí las nociones de la tradición occidental que conformarían el discurso de la razón poética y la manera cómo son planteadas por María Zambrano. Su pensamiento examina las posibilidades de la palabra, la poética y la filosófica, para la elaboración consciente de la persona; e intenta unificarlas mediante una noción de amor que como intencionalidad originaria a la sensibilidad, del trato con la alteridad, le permita al ser humano una reflexión consciente sobre la afectividad. Para lograrlo, hace la revisión de la cultura para encontrar las ideas y los ejemplos que le permitan sostener a la razón poética, en tanto reflexión amorosa y esperanza, como una posibilidad de la subjetividad occidental para conocerse a sí misma desde la afectividad.

Palabras Claves:Afectividad, piedad, amor, alteridad, conciencia.

\begin{abstract}
Here they are revised notions of the Western tradition that conform the discourse of poetic reason, and the way that Maria Zambrano assumed them. Her thought examines the possibilities of the words, either poetic or philosophical, to
\end{abstract}


allow persons to get conscience. She attempts to unify both types of words using a notion of love as essential intent for dealing with the otherness, allowing, also, the human being conscious reflection on the affectivity. To achieve this, she revises culture to find ideas and examples to support the poetic reason as loving and hopeful reflection and as a possibility of the humanity to know about its own feelings.

Keywords: Affectivity, piety, love, otherness, conscience.

\section{Introducción}

La intención de este escrito es señalar cómo sería la afectividad de una subjetividad conciente de sí y comprometida íntimamente con la reflexión sobre lo humano y su transitar en la propuesta de María Zambrano (1904-1991), asunto este que -nos parece- queda sugerido a lo largo de casi todos sus textos, al menos de los más importantes, dándole a su discurso una particular coherencia. La pensadora española apela al valor de la palabra para asumir un tipo de razón donde el sujeto pensante no se separe de la afectación que sobre sí ejerce la realidad, pues sería desde esa relación sensible como el compromiso personal quedaría manifiesto, cualquiera sea el tipo que se asuma, y donde una acción creadora podría evidenciarse. No se trata de defender la validez del pensamiento meramente personalista, encerrado en la propias vivencias; por el contrario, la autora respalda la pertinencia de una reflexión que trascienda la inmanencia del puro subjetivismo, mas sin obviar los padecimientos sensibles que estructuran la experiencia. Tal posibilidad sólo sería realizable desde una particular actitud ante el mundo y ante la vida, la que intentaremos aquí precisar. La palabra de la razón defendida por Zambrano -la llamada razón poética- no sería el simple anuncio de un padecimiento individual que necesite expresarse, ni tampoco una manera abstracta, ideal o formal, de nombrar lo contemplado y ajeno al sujeto del pensamiento. Una verdad trascendente revelada en la palabra seguirá siendo - como ha sido para la tradición- la forma más exacta de conciencia; pero la reflexión zambraniana toma -también de cierta tradición- un referente preciso en el sentir con el que pretende revelar algo profundamente humano y no por eso solamente subjetivo: el amor. La pensadora andaluza asume que lo dicho por la palabra está siempre vinculado -seamos o no conscientes de ello- con ese fondo trascendente de la sensibilidad, esto es: con la facultad intuitiva de la humanidad para relacionarse y con la posibilidad de reconocerse reflexivamente en su experiencia afectiva.

Para trazar un sendero que pueda transitar la sensibilidad hacía una conciencia de sí y de su participación en el mundo -que sería la labor cardinal de una razón poética-Zambrano revisa en la tradición occidental aquellos conocimientos, méto- 
dos o caminos dados en la historia, que han permitido explorar las movilidades anímicas con relación al acto de pensar; y lo hace sin caer en el relativismo escéptico de la actualidad. Es decir, que sin pretender desmontar per se las nociones del pasado, la escritora que nos ocupa les da una lectura que permite rescatar algunos aspectos que puedan ayudar a darle algún sentido trascendente a la existencia humana, o al menos a la elaborada por la conflictiva y paradójica historia de Europa y, por supuesto, la de Occidente. El pensamiento zambraniano puede ser leído, entonces, como una particular mirada a la cultura europea donde se revisan las áreas del saber en relación con aquellos matices que no fueron del todo aceptados por el pensamiento dominante de la modernidad.

Para escrutar aquellos fundamentos históricos que la razón poética haya podido heredar, la pensadora revisa los intereses y las posturas delineadas por la erudición cultural. Con el tiempo, va esbozando una posición que recoge los detalles anímicos que habrían dado cabida a la formación del sujeto como tema característico del pensamiento occidental. Al hacerlo, Zambrano quiere sustentar la importancia de una reflexión atenta a los vaivenes de la sensibilidad con los que la humanidad ha sido, y es aún, capaz de imaginar, soñar y hasta vislumbrar un sentido trascendente de su existencia. Desde esta visión, ${ }^{1}$ larazón poética -que sigue una tradición de raigambre platónica- apela a una vivencia extrema de la sensibilidad, la experiencia del vacío anímico, que ocasiona la certidumbre emotiva de una íntima soledad. A partir esa vivencia - cuando nace de una vivencia amorosa plena ${ }^{2}$ - podría hacerse la única eventual garantía de reconocimiento efectivo, por afectivo, con el otro, con lo Otro, con la alteridad.

La mayor dificultad para estudiar el pensamiento zambraniano radica en que sus textos muestran una elaboración intelectual que no pretende razonar con argumentación puramente conceptual, sino que apela a las certezas y a las dudas de la afectividad para plantear sus discursos. En sus escritos hay una constante referencia a temas clásicos del pensamiento filosófico pero con pocas alusiones directas a los textos donde tales temas son tratados; hay, por esto, que volver y repasar continuamente a aquellos pensadores a los que las reflexiones propias son llevadas por las sugerencias de las palabras de la pensadora aquí estudiada. De cualquier forma, no

1 "La visión es una forma de conocimiento en que lo humano, inaccesible, se manifiesta más adecuadamente, y que más que conocimiento objetivo es expresión. Y podríamos sorprender en la 'visión' el carácter peculiar del conocimiento que el hombre alcanza a tener de su propia realidad: una especie de revelación que padece al mismo tiempo que realiza. Conocimiento poético en su raíz, aunque esté asistido de la más estricta disciplina, de los métodos más rigurosos de investigación." Zambrano, M.: El hombre y lo divino, México, F. C. E., 1973, p. 246.

2 "La historia nos muestra a los que de verdad amaron sumergidos en una especial soledad; soledad hasta física, retiro al desierto que ha precedido a las manifestaciones de las grandes vocaciones amorosas. Porque el amor nace de la soledad del ser en sus tinieblas, que fía en el logro final; nace de la fe ciega." Ibíd., p. 295. 
se trata aquí de oponer posiciones sino de hallar algún sentido coherente y comprensible en las posturas zambranianas sobre el pensamiento europeo, y de vislumbrar sus coordenadas y sus límites; es decir, hallar una referencia cultural en su propuesta que nos ayude a aceptar su eventual validez.

El pensamiento zambraniano podría catalogarse como un particular seguidor de las tendencias vitalistas de principios del siglo XX, ya que sus intenciones se acercan a aquellas doctrinas que centran las reflexiones en cómo puede la vida personal adquirir un sentido valedero sin necesidad de asumir a priori formalismos intelectuales. Para hacerlo, Zambrano apela a una conciencia racional de calibre compresiva que lejos de satisfacerse en sus propias deducciones, se interesa por aquellos asuntos que no logra determinar conceptualmente. La certeza ofrecida por una verdad estaría profundamente unida a la preparación del propio sujeto para elaborarla, para asumirla, aceptando siempre la otredad entendida como aquello que la subjetividad no logra comprender del todo, lo que se le resiste al pensamiento. La palabra tendría en esto una labor fundacional: ser el registro actuante de una relación. Con una metodología fenoménica muy personal, ${ }^{3}$ que lee y reflexiona desde la experiencia personal y lo menos posible desde las abstracciones conceptuales, Zambrano trata de alcanzar una sabiduría allegada a la vivencia, una sabiduría que podríamos llamar "práctica" por la inherencia que tiene en la acción y la conducta, aunque no se trate de un saber de inclinación moralista; su escritura y su racionalidad no se separan nunca del padecimiento. Lo importante no estaría en una objetividad precisa sobre los asuntos reflexionados sino en la posibilidad humana que la actividad reflexiva puede ofrecer para dilucidar la propia vida y la social. Se trata de un pensamiento que busca las raíces comunes del pensar y del sentir, de la vida anímica en todas sus dimensiones.

Este ensayo intenta reconocer, entonces, algunas nociones de la tradición occidental que conformarían el discurso de la razón poética y cómo son planteadas por

\footnotetext{
3 Señala Ann Bundgaard: "No se encuentran en la obra de Zambrano, a diferencia de lo que sí hizo Scheler con relación a Husserl, referencias explícitas sobre cuáles son las confluencias o diferencias entre ella y otros fenomenólogos. La fenomenología de los afectos y la teoría de los valores de Scheler sí parecen haber dejado huella en los escritos zambranianos. Las descripciones fenomenológicas de Scheler dan prioridad al examen de la intencionalidad emocional frente a la intencionalidad intelectual de Husserl. Nuestra autora, siguiendo a Scheler, parece buscar una mayor radicalidad fenomenológica que la de Husserl, ya que ella no parece apuntar a una fenomenología de contenidos de conciencia sino de 'hechos' esenciales y radicales, inconscientes en muchos casos, y no aptos para una inteligibilidad racional. En la investigación de la esencialidad de los valores, Scheler vincula lo a priori con lo material mediante la descripción fenomenológica de las vivencia afectivas y, en muchos casos, rompe con la fenomenología para seguir el método hermenéutico. En esas investigaciones, Scheler sigue una línea de pensamiento que se encuentra entre los representantes de las 'razones del corazón', como lo habían sido Agustín, Pascal, Spinoza y Nietzsche. Estos son también los hitos del pensamiento occidental en los que Zambrano se inscribe." En Más allá de la filosofía, Editorial Trotta S. A. Madrid, 2000, p. 438-439.
} 
la pensadora que nos ocupa; a saber: la reflexión sobre la vida humana, la posibilidad de la conciencia, la formación de la persona, el reconocimiento de sí y de la alteridad. La labor intelectual de Zambrano se fue forjando en lecturas muy personales, en relación con sus propias vivencias, ${ }^{4}$ de las principales corrientes del pensamiento, y siempre en referencia a aquellos aspectos que el determinismo racional tiende a dejar de lado: las vicisitudes del ánimo, las inclinaciones personales, las creencias afectivas. De ahí la importancia que tiene en ella la vinculación del pensamiento con las producciones poéticas (artísticas) que paralelamente a la construcción intelectual fueron floreciendo como testimonios de la vivencia humana.

\section{Los sustentos del ánimo: Palabra e imagen}

El discurso zambraniano parte de la tensión dejada como herencia por el pensamiento de Platón sobre las facultades cognoscitivas. ${ }^{5}$ Sus reflexiones sobre el dilema platónico entre logos y pensamiento, quedaron expuestas en las clases y las conferencias que formaron sus primeros libros sobre la cultura española y la occidental. ${ }^{6}$ Ese problema fue objeto de continuas y variadas lecturas a lo largo de toda su vida de escritora, muchas veces solapado bajo las distintas reflexiones que abordaba sobre el hacer cultural de su tiempo. Para Zambrano, el sujeto occidental se haya constituido originalmente por la tensión entre las dos formas de la palabra que desde

\footnotetext{
${ }^{4}$ En el año 1974 escribe a Agustín Andreu: "El alma nuestra se nos va, como se nos va la palabra -lo sé por experiencia, ya sabes que en teologías no me meto, me mete mi experiencia. Entiendo por experiencia el saber trágico -Esquilo- que Zeus había de aprender padeciendo-. Según Santo Tomás, la mística ¿no es el conocimiento experimental de Dios? Pues en eso estamos, queramos o no queramos." Hace así énfasis en el valor de la vivencia, del padecimiento, dentro de las reflexiones más trascendentes. En Zambrano, M.: Cartas de La Pièce. Correspondencia con Agustín Andreu, Pre-TextosUniversidad Politécnica de Valencia, Valencia-España, 2002, p. 80.

5 "Es en Platón donde encontramos entablada la lucha con todo su vigor, entre las dos formas de la palabra, resuelta triunfalmente para el logos del pensamiento filosófico, decidiéndose lo que pudiéramos llamar 'la condenación de la poesía'; inaugurándose en el mundo de occidente, la vida azarosa y como al margen de la ley, de la poesía, su caminar por estrechos senderos, su andar errabundo y a ratos extraviado, su locura creciente, su maldición. Desde que el pensamiento consumó su 'toma de poder', la poesía se quedó a vivir en los arrabales, arisca y desgarrada diciendo a voz en grito todas las verdades inconvenientes; terriblemente indiscreta y en rebeldía. Porque los filósofos no han gobernado aún ninguna república, la razón por ellos establecida ha ejercido un imperio decisivo en el conocimiento, y aquello que no era radicalmente racional, con curiosas alternativas, o ha sufrido su fascinación, o se ha alzado en rebeldía." Zambrano, M.: Filosofía y poesía, F. C. E., México, 1993, p. 14.

${ }^{6}$ Las más importantes están recogidas en Pensamiento y poesía en la vida española y en Filosofía y Poesía; libros editados en el año de 1939, cuando, tras la Guerra Civil, había salido exiliada de España y procuraba hacerse una lugar en el continente americano. Anteriormente había escrito el libro Horizonte del Liberalismo y muchos artículos bajo la ingerencia -fundamental aunque no exclusivade la problemática política vivida en España en los años de la República.
} 
la autoridad de la filosofía en el discurso platónico -más precisamente desde el libro $\mathrm{X}$ de la República- quedó bosquejada en el ánimo europeo. Platón establecía una disyuntiva radical entre los valores morales y gnoseológicos de la palabra poética y la palabra filosófica, reconociendo y asumiendo sólo la veracidad ética de la filosofía. Así quedaría marcada la dualidad radical que determinará la subjetividad occidental: por un lado, la conducta poética que implica una aceptación inmediata de las vivencias y una actitud de receptividad ante lo que a la sensibilidad se presenta, por muy tormentosa que pudiera ser; por el otro, la conducta filosófica que abre una brecha en la sensibilidad desde donde se intenta salvar al hombre del padecimiento afectivo.

A pesar de que en algunos mortales afortunados, poesía y pensamiento hayan podido darse al mismo tiempo y paralelamente, a pesar de que en otros más afortunados todavía, poesía y pensamiento hayan podido trabarse en una sola forma expresiva, la verdad es que pensamiento y poesía se enfrentan con toda gravedad a lo largo de nuestra cultura. Cada una de ellas quiere para sí eternamente el alma donde anida. Y su doble tirón puede ser la causa de algunas vocaciones malogradas y de mucha angustia sin término anegada en la esterilidad. ${ }^{7}$

Con la filosofía -explica Zambrano- nació una distancia vigilante de la sensación, una distancia que se proyectaba en Platón como una esperanza de salvación ante el dolor que lo transitorio de la vida sensorial ofrece irremediablemente, y al que los poetas se han empeñado siempre en cantar. De esa distancia del pensamiento nacerían las diferencias entre la palabra poética y la palabra filosófica: la primera intenta resguardarse, apoyarse, en lo sensible, mientras que la segunda se proyecta hacia una concepción racional, hacia lo ideal, aunque ambas busquen una misma verdad. ${ }^{8}$ Este conflicto encierra una serie de problemas relacionados con la noción que la humanidad pueda tener de su propia condición en el mundo, a saber: la manera como se manifiesta la verdad en el ánimo humano, la valoración de esa verdad y las implicaciones morales que un juicio sobre la verdad acarrea. Además, la palabra filosófica prometía una eventual superación del pathos que aqueja la temporalidad humana, una promesa de inmortalidad felicidad que libraría al alma de sus tormentos mundanos; sobre esta promesa Platón sustentará el poder del pensamiento dialéctico. "Así Platón en su afán por la independencia humana, por su hacer salir al hombre del orbe de la tragedia, reunió el contenido humano y lo puso bajo el mando

\footnotetext{
7 Zambrano, M.: Ob. cit., p. 13.

8 Con la poesía cristiana se producirá en Occidente una particular alianza, mediada por la religión, entre la esperanza ideal de la filosofía y el apego poético a la sensibilidad que Zambrano revisará con mucho detenimiento. Los grandes ejemplos zambranianos de esta unión serán Dante Alighieri y san Juan de la Cruz.
} 
de la razón. Pues que al fin, por la razón existía el hombre y se liberaba de los dioses tiránicos". 9

Pero la palabra -entiende Zambrano- está ligada estrechamente a la vida. Intenta, entonces, concebir una palabra desprendida del carácter de signo arbitrario y convencional para que asuma la función de virtual descifradora de una realidad vivida, como supone lo habría sido originalmente. Si para Platón la palabra verdadera estaba referida más a la idea que a la imagen sensible también por el logos aludida, 10 en Zambrano tal referencia estará ligada estrechamente a una vivencia, a una relación afectiva que anhela su propia trascendencia. Y es que la palabra al nombrar la realidad, al juzgarla, también la conforma, la dibuja, he ahí su virtud y su riesgo. Mediante su empleo la humanidad ha fundamentado - de infinitas maneras-el lugar de la diferenciación, de lo uno y de lo otro, y con esto ha intentado delimitar los espacios y los tiempos donde ha concebido su propio transitar.

Zambrano acepta, no obstante, que lo más peculiar de la posición platónica estaba en que con la razón se abría la posibilidad de acceder a una libertad humana enfrentada a la justicia divina imposible de precisar. La Justicia postulada por la dialéctica del pensamiento sería una justicia que resguardaría al hombre de aquellas oscuras fuerzas -las trágicas- que lo ofuscan y en las que no pude inmiscuirse, de las que sólo podrá escaparse por la mediación racional. La palabra filosófica fue presentada por Platón como un camino de esperanza ofrecido por la misma inteligencia del hombre, como su habilidad más esperanzadora. Con esta propuesta, quedó abierta la posibilidad de una justicia humana, y con ello se centró en la conducta humana el problema primordial de la reflexión. Además, en esa esperanza la filosofía platónica resguardaba para el alma una cualidad amorosa que, a pesar de sus intenciones de desapegarse de lo puramente sensible, se mostraba como el esen-

\footnotetext{
9 Zambrano, M.: Ob. cit., p. 32

$10 \mathrm{La}$ lectura de la referencia sólo ideal del logos platónico parece ser más una herencia cultural que propiamente una posición del divino ateniense, quien se mantenía al respecto en cierta ambigüedad referencial. Al respecto menciona Juan David García Bacca dos acepciones simultáneas que aceptaba la palabra Idea en los diálogos platónicos: “a) 'Idea' es 'aspecto visual típico de algo', -cual joven 'bello de idea', 'bello de ver', 'bello de aspecto', o de aspecto bello. b) 'Idea' suena además a 'significado' propio, característica de algo: 'a lo meramente visible, a mirar de intento en una cosa', -casi lo que solemos llamar su idea. Que hablando Sócrates con un joven 'bello de idea' (a) - (...)- emplee sin reparo ni maliciosa ambigüedad la palabra 'idea', o la de 'eidos', en su calidad de sonante a 'idea'; o la emplee según (b), 'a lo mentalmente visible', 'hacia lo que precisamente se debe mirar' en una cosa bella o vulgar, ..., debe advertirnos que, justamente por estar siendo aún 'idea' palabra 'acorde' con esas dos notas $(a, b)$, el pasar de un significado al otro - tan inconexos ya para nosotros, y el pasar de un significado al otro tan maliciosamente ambiguo para algunos- era un paso natural, aún, pues, sonaban ambos, a la par (acordes), aunque con intensidad cambiable, indicada, tal vez, por el énfasis en la pronunciación...". "Clave Hermenéutica". En Platón: Obras Completas, Facultad de Humanidades y Educación Universidad Central de Venezuela, Caracas, 1980. p. 60-61. Tomo I. Es con el neoplatonismo de Plotino, en el siglo III, que las ideas, absortas ante lo Uno, serán desvinculadas de la imagen.
} 
cial anhelo humano de trascendencia, como un intento vivo y vivaz por superar el padecimiento y encontrar la unidad fundante en la que la existencia pudiera sustentarse con toda la plenitud y la dignidad posibles. Zambrano le será fiel a este anhelo; por él se recobraría el valor esencial de toda palabra, ya sea la filosófica ya sea la poética, como medida de lo humano.

El pensamiento zambraniano discierne entre la importancia de la imagen y el valor del concepto, las dos formas que toma la palabra, en la formación de la subjetividad. En 1937, en plena a Guerra Civil, escribe Zambrano:

En la incertidumbre que es la vida, los conceptos son límites en que encerramos las cosas, zonas de seguridad en la sorpresa continua de los acontecimientos. Sin ellos la vida no saldría de la angustia en que permanecería estancada, a no ser que fuera permanente felicidad, presencia total, revelación completa de todo cuanto nos importa. ${ }^{11}$

No obstante, el valor que entonces daba a los conceptos variará en la medida que indagaba en las cualidades de la razón poética y exploraba en las posibilidades sapienciales de la imagen, aunque reconoció siempre la importancia occidental a ellos dada. ${ }^{12}$ Para la pensadora malagueña la imagen, más que el concepto, revela con mayor precisión la raíz afectiva que mueve a la humanidad. Las imágenes aluden al primer trato, al trato original, del hombre con la realidad; gracias a ellas se abrió el espacio propicio para que el hombre se pensara a sí mismo y a lo que lo rodea. 13 Toda imagen -asume Zambrano-revela todavía algo de un vacío anímico originario que el concepto tiende a obviar, sin lograrlo nunca plenamente. La ambigüedad de sentido de ese vacío sustentado en una figura sirve, más que la determinación conceptual, como la señalización de un sendero por donde lo humano está

11 Zambrano, M.: "La reforma del entendimiento español". En Los intelectuales en el drama de España y escritos de la guerra civil, Editorial Trotta, Madrid, 1998, p. 152.

12 En 1983 escribe: "El concepto descubierto por el filosofar de Sócrates abrió una ancha vía, un camino real al pensamiento occidental que lo recorrerá hasta su fin. La mente occidental cobrará su "ser" -si tal expresión puede usarse- definitivamente, como si con el concepto se hubiese decidido su destino: su vocación, su vía entre todas, la verdad, es decir el modo de verdad que aún hoy se propone. El concepto forjado en el entendimiento con la palabra que le corresponde." Zambrano, M.: "La balanza". En Notas de un método, Mondadori, Madrid, 1989, p. 44.

13 "Pues en el principio era el delirio; el deliro visionario del Caos y la ciega noche. La realidad agobia y no se sabe su nombre. Es continua ya que todo lo llena y no ha aparecido todavía el espacio, conquista lenta y trabajosa. Tanto o más que la del tiempo. Lo primero que se precisa para la aparición del espacio libre, dentro del cual el hombre no se tropiece con algo, es concretar la realidad, en la forma de irla identificando, de ir descubriendo en ella entidades, unidades cualitativas. Es el discernimiento primero, muy anterior al lógico, a la especificación de la realidad en géneros y especias, y que la prepara. No hay 'cosas' ni seres todavía en esta situación; solamente quedarán visibles después de que los dioses han aparecido y tienen nombre y figura. (...) Y esta primera forma de trato con la realidad tenía que darse en una imagen.” Zambrano, M.: El hombre y lo divino, México, F. C. E, 1973, p. 30. En imágenes divinas que permiten las diferentes culturas. 
llamado a divagar afectivamente, como si los sentimientos y los afectos necesitaran alusiones algo indeterminadas para hallar, por ellos mismos, algún entendimiento. Las imágenes divinas serían los más claros ejemplos: "Pues que los dioses se dan también sobre un fondo opaco. Y la transparencia es su promesa que no pueden cumplir, esa que más ofrecen conforme se van acercando a ser dioses verdaderos, no dioses de verdad, sino verdaderos." 14

La imagen, cuando nos muestra su realidad, se presenta como un enigma radical que apura en el sujeto la necesidad de hallar una referencia vital que la fundamente."Ya que todo lo que el hombre hace tiene, además del sentido primario, otro sentido, por lo menos, más oculto y recóndito que luego salta a la vista. Y así sucede con lo que mira y discierne, con lo que fija su atención. Nada es solamente lo que es." 15 La importancia de una imagen, al señalar más radicalmente que la objetividad del concepto un tipo de relación con el misterio, con la alteridad desconocida, con el anhelo de una vinculación afectiva, estará referida a la incidencia directa de lo real en el sujeto y a la manera como esa subjetividad se concibe a sí misma, o intenta hacerlo. En este sentido, cuando una imagen dada en la vigilia nos incide con toda su carga de realidad, sentimos como si se nos abriera una nueva posibilidad de vida distinta a la que hasta entonces hemos llevado, la aceptemos o no.La peculiaridad de una imagen así -propone el pensamiento zambraniano- radicaría en la exigencia de ser asumida enteramente por el ánimo, como si su aparición nos señalase una finalidad vital que se nos hace necesario seguir, como un sentido ineludible de vida a recorrer. La imagen sería, entonces, la que señala el inicio de un nuevo tiempo a transitar. Sucede en los sueños que cuando una imagen se muestra con esa carga de realidad, despierta a quien la sueña; algo similar sucede con el encantamiento que nos causa el arte o la poesía; y también cuando, despiertos, sentimos la pertinencia efectiva de una presencia que arroba nuestra atención. Así, la realidad de la imagen, ya sea soñada o padecida en la vigilia, contemplada o leída, queda incluida en la intuición inmediata de finalidad afectiva que sugiere y exige. Una imagen con la fuerza de una certera realidad y no de noticia circunstancial, sería aquella capaz de señalar, con su polivalentes referencias, un camino que la afectividad -personal o colectiva- está dispuesta a asumir, un sendero anímico por donde la subjetividad está llamada a caminar. 16 Entiende Zambrano que la función de la imaginación es la de abrir caminos al conocimiento, y esa apertura se siente

\footnotetext{
14 Zambrano, M.: De la Aurora, Ediciones Turner, Madrid, 1986, p. 13.

15 Zambrano, M.: Notas de un método, Mondadori, Madrid, 1989, p. 119.

16 La imagen en Zambrano es siempre un lugar de mediación, tal como lo plantea la corriente analítica jungiana. Escribe, por ejemplo, James Hillman: "Cada imagen combina en su interior cualidades de la conciencia y cualidades del mundo, que expresan, mediante la misma imagen, la compenetración de la conciencia y el mundo, pero siempre y únicamente como imagen fundamental de esa combinación." El pensamiento del corazón, Siruela, Madrid, 1999, p. 20.
} 
precisamente por esa posibilidad de vacío que toda imagen (siempre aparencial, en sentido platónico) ofrece. En este sentido, la realidad de una imagen -ya se presente como un recuerdo voluntario o involuntario, ya sea leída o soñada, o simplemente vislumbrada en la vigilia- muestra ante quien la recibe las afectividades que palpitan en su subjetividad, y puede, por esto, hacerse fácilmente icono o volverse un objeto de adoración (ídolo). Esas figuras o formas surgidas de un fondo ausente e inefable presentan su realidad en un cúmulos de vivencias unificadas en la imagen ofrecida; su validez casi absoluta en la afectividad humana radicaría justamente en ello. ${ }^{17}$ Por el contrario, la eficacia de un concepto no es medible por la sensación de vacío que la imagen señala incitando a la fantasía; en su precisión abstracta, en su determinación, el concepto se olvida de la anhelante ausencia manifiesta al sentir y no quiere aludir inmediatamente a ninguna afectividad, aunque hable de ella. Por esto mismo, la imagen es en Zambrano más primordial que el concepto para indagar en la sabiduría intuitiva u original del humano. 18

\section{Una actitud piadosa}

Ahora bien, para que la multiplicidad de referentes a los que la imagen remite en su unidad presencial pueda ser tomada en toda su potencialidad de sentido, en su realidad más completa, ${ }^{19}$ para que su misterio pueda acogerse de la manera más integral, habría que acercarse a ella piadosamente. Y esto denota en el pensamiento zambraniano relacionarse sin determinaciones preconcebidas que encaucen de antemano las posibilidades de un trato afectivo, de una relación sensible encaminada a expandirse en la temporalidad. La piedad sería, en primer instancia, una inten-

\footnotetext{
17 "La imagen, aun considerada en sí misma, es múltiple, aunque esté sola. La conciencia la sostiene sabiéndola imagen. Y la posibilidad se abre a su lado; podría ser diferente y es quizás así, tal como se da a ver. Su ser de abstracción no le da fijeza, más que cuando un intenso sentimiento se le une. Y entonces asciende a ser icono: el icono forjado por el amor, por el odio, por el concepto mismo, especialmente cuando la imagen encierra una finalidad.” Zambrano, M.: Claros del bosque, Seix Barral, Barcelona, 1993, p. 119.

18 Incluso la filosofía, en Grecia, nacería del vacío dejado por las imágenes de sus dioses, la inestabilidad del constante cambio de las imágenes míticas habría conducido a la pregunta sobre el ser de las cosas y, luego, sobre el ser del hombre. Reconoce Zambrano que esta idea la toma directamente de su maestro madrileño: "Ortega y Gasset, en una lección del curso: 'Tesis metafísica sobre la razón histórica', dado en la Universidad de Madrid en el año 1935, expuso, con la claridad que le es propia, la tesis de que fue el vacío de ser habido en los dioses griegos el que provocó en el hombre la nostalgia, el echarse de menos y, por lo tanto, la decisión de buscarlo no en los dioses, sino en las cosas de la naturaleza." Zambrano, M.: El hombre y lo divino, p 60, nota 1.

19 "Pues realidad es no sólo la que el pensamiento ha podido captar y definir sino esa otra que queda indefinible e imperceptible, esa que rodea a la conciencia, destacándola como isla de luz en medio de las tinieblas." Ob. cit., p. 191.
} 
ción de trato con lo extraño, con la presencia de lo ajeno a la comprensión. Intencionalidad anímica que en el pasado propició los distintos ritos religiosos de acercamiento a los dioses (los sacrificios) y más tarde, desde Platón y la filosofía consiguiente, la ética humana. Escribe Zambrano, la piedad, "Es, quizá, el sentimiento inicial, el más amplio y hondo; algo así como la patria de todos los demás." 20 Como sentimiento original, la piedad abriría la posibilidad de trato con "lo otro", con lo difícil de manejar desde el entendimiento, desafiando los límites del transitar anímico mas sin desquiciar la siempre frágil entereza afectiva. ${ }^{21}$ Asumirla, sería principio de libertad por la posibilidad que ofrece para dilucidar "algo" de las tensiones irracionales de las entrañas del ser.

Pues bien, llamamos Piedad a este sentir cuando es sentido por un sujeto, por alguien que siente, no la realidad en un modo difuso y homogéneo, sino las "especies" o géneros de realidades que, de algún modo, ha de tener propicias. Una criatura que siente la realidad y al mismo tiempo se siente a sí mismo heterogéneo de ella. Conciencia de soledad al par que conciencia de participación, de trato. Mientras que el racionalista, aparte de que crea que la realidad se le da en una idea o pensamiento, cree también que sólo reduciendo la realidad a pensamiento puede entenderse con ella. Piedad es sentimiento de la heterogeneidad del ser, de la cualidad del ser, y es anhelo por tanto de encontrar los tratos y los modos de entenderse con cada una de esas maneras múltiples de la realidad. 22

Una actitud piadosa representaría, entonces, el principio de una sabiduría sobre la sensibilidad, el origen de una intencionalidad afectiva que comienza reconocerse.

Para sostener esta concepción del sentimiento piadoso, la pensadora española revisa -en El hombre y lo divino- el diálogo platónico Eutifron, donde quedó señalada la importante variación conceptual respecto al sentido de la piedad realizada por el naciente -para la época de Platón ya floreciente- pensamiento racional. Nuestra autora lee en la concepción de la piedad defendida por un adivino ateniense que le da nombre al diálogo - esto es: la piedad como trato adecuado con los dio$\operatorname{ses}^{23}-$ un asunto relacional en el que la virtud propiamente humana poco tendría

\footnotetext{
20 Zambrano, M.: Para una historia de la piedad, Torre de las palomas, Málaga, 1989, p.13.

21 "La Piedad no puede definirse, menos que ningún otro sentimiento porque constituye el género supremo de una clase de ellos: de los sentimientos amorosos o positivos. No es el amor propiamente dicho en ninguna de sus formas y acepciones; no es tampoco la caridad, forma determinada de la piedad descubierta por el Cristianismo; no es la compasión, pasión más genérica y difusa. Viene a ser la prehistoria de todos los sentimientos positivos. Y, sin embargo, les acompaña en su historia y aun llega a tenerla ella misma." Ob. cit., p. 14.

22 Ob. cit., pp. 20-21.

23 "Lo que es amable a los Dioses es pío; y lo que no es a ellos amables es impío" (Eutifron, 7a.) "Esta es pues mi opinión, Sócrates: que lo Sacro y lo Pío son precisamente esa parte de la justicia que cultiva el trato con los dioses, mientras que lo restante de la justicia cultiva el de los hombres." (12e)
} 
que decir, pues una intencionalidad verdaderamente piadosa se revelaría en la manifestación de los dioses en los actos humanos como retribución ante una actitud de respeto o sumisión para con ellos, y sólo así se revelaría lo justo. Evidentemente, durante todo el diálogo la posición de Eutifron va siendo desestimada por Sócrates al considerarla imprecisa ante la variabilidad infinita de temperamentos divinos y sus múltiples discrepancias. La piedad termina siendo concebida como una virtud moral, asumida desde la racionalidad.

Y así vemos en el breve diálogo Eutifron algo sumamente delator... La piedad se define primero como el trato adecuado con los dioses, para acabar reconocida como un virtud, es decir, un modo de ser del hombre justo. Se ha verificado una conversión típica de la doctrina del ser y quizá más evidente aquí que en otras cuestiones: lo que era trato, relación, sentimiento, supeditación, quizá, del hombre a realidades de otro plano -a realidades otras- ha quedado convertido en un ser del hombre. 24

A partir de entonces, la filosofía valorará éticamente al sentimiento pío. Pero será más tarde, con la tradición casi anónima del estoicismo, por la aceptación popular que este pensamiento ha tenido en el pueblo europeo, cuando la piedad -según Zambrano- adquirirá toda su importancia como virtud humana. 25 "El estoicismo será así la solución clásica y duradera de la piedad desde el ser, y por tanto del mundo sagrado en el mundo del ser y del pensamiento."26 Y aunque mantendrá todavía algo del sacrificio primigenio como intento de trato con lo sagrado -aque-

24 Zambrano, M.: El hombre y lo divino, Ob. cit., p. 205.

25 Escribe Zambrano sobre la época histórica cuando florece el pensamiento estoico, desde el siglo III antes de Cristo hasta finales del siglo III de nuestra era: "Por primera vez nos topamos con un hombre desarraigado, a quien los lazos de la sangre, la comunidad patria o la obediencia religiosa no bastan para conducir su vida. El cosmopolitismo estoico, aparte de su exageración, tiene, sin duda, este significado; el hombre se siente sólo, sin conexiones sanguíneas, raciales ni religiosas, y por eso se siente intercambiable. No lleva sobre sus hombros el peso de un destino concreto, se siente desamparado y en su desamparo descubre la individualidad, que, claro está, es universal." ("Un camino español: Séneca o la resignación”. En Los intelectuales en el drama de España y escritos de la guerra civil, Ob. cit., p. 195.) Junto al estoicismo aparecen otras importantes escuelas, el cinismo y el epicureismo, que a pesar de su importancia dentro del ámbito erudito, no tuvieron la aceptación popular que ha tenido siempre el pensamiento estoico en los pueblos europeos, sobre todo en los españoles. En El hombre y lo divino explica, en referencia al tema de la piedad, esta vigencia y su constante renacer: "El cinismo desesperado oscila ante la piedad, se deja devorar por ella. Epicuro responde con el cálculo excesivo y temeroso. Sólo el estoicismo producirá esa calma profunda unida al entusiasmo propia de las soluciones verdaderas de los grandes conflictos. Su duración, su capacidad, hasta ahora indefinida de renacimiento, lo dice también. Y aun hay otra prueba: su capacidad de anonimato, de infundirse por vías intrahistóricas y persistir sin nombre y sin apenas tradición escrita, porque nos referimos a las venerables culturas analfabetas, límites extremos de la piedad de la inteligencia que logra descender a quienes no pueden fatigarse en perseguirla, como una forma de la poesía y de la gracia." Ob. cit., p. 214-215.

26 Ob. cit., p. 215. 
llo que en el caso de Séneca toma el nombre de "resignación" como la sumisión ante una "razón cósmica" de la que todos participamos pero incomprensible para la mente humana-, la piedad sería desde entonces aceptada como una virtud moral capaz de cultivarse, a voluntad, en la interioridad del hombre. La ilustrada y racional "tolerancia" será su concepción más moderna. ${ }^{27}$

No obstante, Zambrano reconoce en la tragedia ática un ritual literario que resguardó para Occidente la importancia y el valor de la antigua concepción de la piedad, precisamente por su indagación de las oscuras pulsaciones que movían a una sociedad ya iniciada en la racionalidad filosófica. ${ }^{28}$ La poesía trágica, en tanto elaboración con la palabra, abrió un camino paralelo y divergente al emprendido por la filosofía en los mismos tiempos del esplendor griego. El teatro trágico, actividad descendiente de los antiguos rituales, trataba sobre los padecimientos emotivos que, mediante una imagen poética tomada de la tradición religiosa, se mostraban en una sociedad ya encaminada por los predios de la razón y del sentido común (al menos en los círculos intelectuales y poderosos). ${ }^{29}$ Según los estudiosos de la cultura helénica, parece difícil obviar en la tragedia la participación de esas tres las actividades sobre las que se fundó la vida griega: religión, arte y filosofía. ${ }^{30}$

27 "La idea de que el hombre es, ante todo, conciencia y razón ha llevado a que el hombre sólo se considere semejante a otro hombre. Mas no se detiene ahí el proceso, pues como las diferencias entre los hombres subsisten, y hay razas, nacionalidades, culturas, clases sociales y diferencias económicas, hemos llegado al espectáculo bien visible de la sociedad actual. Apenas sabemos tratar sino con aquellos que son casi una reproducción de nosotros mismos. El hombre moderno al asomarse al mundo va buscando un espejo que le devuelva su imagen y cuando no la encuentra, se desconcierta y, a menudo, quiere romper el espejo. Nos hemos hecho terriblemente incapaces de soportar que haya hombres distintos a nosotros. Se ha inventado, para llenar este vacío, la tolerancia, palabra favorita del léxico del hombre moderno. Pero "tolerancia" no es comprensión, ni trato adecuado, es simplemente, el mantener a distancia respetuosamente, eso sí, aquello con lo cual no se sabe tratar." Zambrano, M.: Para una historia de la piedad, Ob. cit., 1989, pp. 18-19.

${ }^{28}$ En referencia a la relación entre la tragedia y Occidente comenta George Steiner: "Todos los hombres tienen conciencia de la tragedia en la vida. Pero la tragedia como forma teatral no es universal. El arte oriental conoce la violencia, el pesar y los embates de los desastres naturales o provocados; el teatro japonés está repleto de ferocidad y muertes rituales. Pero esa representación del sufrimiento y el heroísmo personales a la que damos el nombre de teatro trágico es privativa de la tradición occidental. (...) Tanto esa noción como la visión del hombre que implica son griegas. Y casi hasta el momento de su decadencia, las formas trágicas son helénicas". La muerte de la tragedia, Monte Ávila Editores, Caracas, 1991, p. 9.

29 Cabe aquí recodar que en su Poética, Aristóteles insiste en que la actividad imitativa de la palabra trágica tenía un lugar dentro del contexto epistemológico, distanciándose así de su maestro Platón. La poesía trágica exigía del poeta una realización imitativa de gran valor cognoscitivo y ofrecía la posibilidad de contemplar placenteramente -diríamos hoy: estéticamente- las vicisitudes humanas.

$30 \mathrm{Al}$ respecto señala Werner Jaeger: "Los contemporáneos no consideraron nunca la naturaleza y la influencia de la tragedia desde un punto de vista exclusivamente artístico. Era hasta tal punto su soberana que la hacían responsable del espíritu de la comunidad. Y aunque como historiadores debemos pensar que los grandes poetas no eran sólo los creadores, sino también los representantes de aquel 
Sobre la relación entre la tragedia y el pensamiento racional escribe Zambrano:

Si la pregunta que da nacimiento a la filosofía hunde sus raíces en la ausencia de ser habida en las imágenes de los dioses, la tragedia nacerá dando figura a las pretensiones de existir, a la pretensión de existir en que consiste la condición humana. Una ausencia del ser también más allá del ser de las cosas y que no podrá "fundar" la filosofía, sino un saber trágico cuya pregunta inicial será la queja, el llanto. 31

Nuestra escritora ve en la tragedia ática una conmemoración colectiva que intentaba interactuar con la alteridad y evidenciar las relaciones afectivas que se resistían a ser controlados por la sola voluntad humana. El espectáculo trágico ofrecía al pueblo griego un espacio colectivo donde la palabra era imagen viva, y dejaba entrever algo de lo innombrable del padecimiento sobre lo que se erigiría tanto la voluntad individual de los héroes, como la emotividad colectiva de los coros. Al hacerlo, dejaba vislumbrar un nudo esencial que pulsaba en los fondos anímicos de esa cultura.

Toda tragedia poética lleva en su centro un sueño que se viene arrastrando desde lejos, desde la noche de los tiempos y que al fin se hace visible. La visibilidad es la acción propia del autor trágico y del sueño mismo trágico. Todo en principio está ahí, en darse a ver y por eso es el despliegue de un instante, un solo instante en que se abre el abismo infernal del ser humano, donde yace aprisionado, en sus propias entrañas. ${ }^{32}$

La elaboración trágica sería, entonces, una actividad mediadora con los estados anímicos que reconocería y mostraría las hondas paradojas del sentir. Y sería, por esto, el abono afectivo para que se cumpliese el despertar de la conciencia ciudadana griega, tan llamada a la reflexión. No se trataba aún de una atención puramente racional, como la reclamada por la filosofía, sino una "conciencia inocente" que sin imponer ni determinar leyes, 33 atendía las turbulentas entrañas humanas que hacían dificultosa la realización plena del "ser racional" reclamado por el discurso filosófico y su nueva moralidad. Por estas razones, es decir, por acercar la visión del pensamiento escrutador a lo que por su dificultad no alcanza a dilucidar con clari-

espíritu, esto no altera en nada la responsabilidad de su función rectora que el pueblo helénico consideró como mayor y más grave que la de los caudillos políticos que se sucedieron en el gobierno constitucional.” Jaeger, W.: Paideia, México, F. C. E, 1985, p. 231.

31 El hombre y lo divino, Ob. cit., p. 64

32 Zambrano, M.: "El origen de la tragedia: Edipo". En El sueño creador, Turner, Madrid, 1986, pp. 82-83.

33 "El despertar de la conciencia puede hacerse cargo del sentir del padecer trágico y no puede darse sino en una conciencia inocente que precede en su acción a la 'conciencia pura' de la filosofía. El despertar trágico es un despertar en los infiernos del ser. La conciencia en que ese despertar se enciende es una conciencia inocente, que no impone su ley. Es una conciencia mediadora que no teme al 'descendimiento'." Ob. cit., p. 81. 
dad sobre las emociones, la tragedia será para Zambrano un oficio piadoso nacido en el esplendor de la cultura griega para hacer participar lo sagrado -el misterio que mantenía viva la antigua religión mítica- en el seno de una sociedad ya altamente refinada intelectualmente. Por esto mismo, el género trágico representará el inicio de la historia de una conciencia poética en la cultura occidental.

La tragedia, hija del Dios escondido, relatará la pasión por la luz, los sufrimientos de la luz misma en sus tránsitos, la luz en su comercio íntimo con la vida que le resiste y la espera, el clamor, en suma, de lo más humano de la condición humana; el ser en conato abierto a la esperanza. Su condición pasiva y trascendente. 34

Para el pensamiento zambraniano, el trato piadoso con la alteridad, del que la tragedia fue ejemplar expresión, alberga y protege el centro oscuro de la afectividad, al que no se accede desde la subjetividad meramente racional pero que forja íntimamente a la persona. Zambrano alude al reconocimiento (anagnórisis) -según Aristóteles elemento esencial de un bello argumento trágico ${ }^{35}$ - para explicar el valor de la experiencia trágica en la formación de la persona como momento fundante de la conciencia. Al reiterar insistentemente que es propio del hombre que vaya haciendo su vida en la medida que busque su trascendencia, ${ }^{36}$ entiende que lo trascendental no se halla en la sola comprensión intelectualsino en un sentido intuido afectivamente y llamado a ser reflexionado. Y esto exige del ánimo una actitud abierta hacia el otro y hacia lo otro, es decir, hacia aquellos ámbitos que evidencian la heterogeneidad del ser, personal o social, difíciles de pensar a cabalidad. En todo reconocimiento trágico, el nacimiento doloroso de la conciencia de sí se hace irrefutable, pues la evidencia de la alteridad, de lo no ha sido reconocido hasta entonces, se muestra con toda su crudeza. La experiencia trágica implicaría el padecimiento y la agnición de una situación particular que ha mantenido imposibilitado de

34 Zambrano, M.: El hombre y lo divino, Ob. cit., p. 65.

35 "Reconocimiento, como el propio nombre lo indica, comporta un cambio de la ignorancia al saber, que [genera] el amor o el odio de quienes están predeterminados para la felicidad o la desdicha. El reconocimiento más bello se produce cuando se da junto con la pericia, como sucede en el Edipo. Hay además otras clases de reconocimientos, pues lo referido puede suceder igualmente con [cosas] inanimadas y con [hechos] casuales, y es posible reconocer si alguien hizo o no hizo tal cosa. Pero la forma más adecuada del argumento y de la acción es la que se ha mencionado, ya que tal especie de reconocimiento y de pericia ha de producir compasión o temor, cuyas manifestaciones, representadas, se supone constituyen la tragedia. Más aún, de tales hechos derivará la buena suerte o la desdicha." Poética 1452 a-b.

36 "Porque el hombre es el ser que padece su propia trascendencia. La padece actualizándola, extrayéndola de la ambigüedad, y aun de la realidad, en un activo padecer. Lo que hace del hombre criatura de experiencia y no sólo de historia; de verdad y no sólo de realidad". (Zambrano, M.: "Advertencia I". En La España de Galdós, Ediciones Endymion, Madrid, 1989, p. 16.) "El hombre es el ser que padece su propia trascendencia. Y, por tanto, padece su realidad: la suya y la realidad en tanto que le es dada, que le concierne." Los sueños y el tiempo. Siruela, Madrid, 1998, p. 21. 
moverse, de salirse de una inercia afectiva, a quien la vive. "Y de ahí esa apertura del ánimo, ese ensanchamiento que adviene en el padecer de la tragedia, y la purificación que no es sino el resultado de haber asumido, por simpatía que llega a los linderos de la visión, el padecer no sólo del protagonista, sino de cualquier posible padecer", 37 reflexiona Zambrano en clara alusión a la catarsis aristotélica.

El género literario de la tragedia anunciaría, entonces, una exigencia que ha sido muy propia de la vocación de ser en Occidente, y que ha determinado en mucho su particular historia: la necesidad de reconocerse a sí mismo, de asumirse a plena conciencia, por dolorosa que pueda resultar. ${ }^{38}$ En la palabra trágica ve nuestra autora la raíz occidental del la razón poética, sobre todo en la figura de Antígona; ya que este personaje anunciaría las posibilidades amorosas de una conciencia más plena, más cercana a la oscura e íntima emotividad. La imagen poética de la doncella tebana es considerada por Zambrano como la anunciante de un nuevo camino emprendido por la cultura occidental hacia una profunda y afectiva realización personal, aún cuando Sócrates la halla sepultado viva junto a los muertos, o justamente por ello. En el encierro de la tumba sería donde la anagnórisis de este personaje, exigencia de todo saber trágico, se haría evidente. En una intimidad radical, la hija de Edipo adquiriría conciencia -y con ella, quien la escuchara- del profundo sentido vital de su apasionada entrega a la conciliación familiar, aunque no haya sido asumida por las históricas circunstancias ni por sus familiares. ${ }^{39}$ Antígona-acentúa nuestra autora- "se encuentra en el peldaño más alto de la escala trágica, en la cima, víctima de sacrificio más que protagonista de simple tragedia." 40 Lo que el aprendizaje trágico de este personaje anunciaría desde su panteón, sería una intimidad anímica de profunda pulsación amorosa que rozaría lo más original del anhelo sensible. La palabra trágica alcanzaría, por su mediación, una conciencia afectiva de las más palmarias intenciones mediadoras de la afectividad; y esto sería ya una razón poética.

Zambrano defiende al amor, en tanto anhelo de relación que fundamenta la humana realidad, como el centro afectivo desde el cual se podrían dilucidar las variantes anímicas de la subjetividad. Según la manera como una subjetividad logre reflexionar sobre las vivencias amorosas, reflexionará también sobre las cualidades

37 El hombre y lo divino, Ob. cit., p. 253

38 Escribe Zambrano: "El conocimiento es el resultado de un método. El saber es algo que nace de una pasión, es decir, de un padecer la verdad de la vida antes de que se presente, de haberla concebido como todo lo que se concibe antes de que nazca." Ob. cit., p. 343 Lo que la tragedia piadosamente ofrece sería sabiduría.

39 Ver Zambrano, M.: La tumba de Antígona. En esta pieza para teatro, las reflexiones que nuestra autora coloca en palabras de la doncella encerrada no la inducen al reconocimiento de alguna culpa moral ni social. La Antígona de Zambrano no se arrepiente ni se duele de los impulsos que la condujeron a vivir entre los muertos. Sí reconoce, en cambio, la fuerza inmortal y desconocida del amor como el pulso de su alma, y a él queda entregada.

40 Zambrano, M. El sueño creador, Ob. cit., p. 82. 
de la temporalidad en que ellas son vividas. Allí quedaría estructurada la intimidad personal en relación con una realidad asumida. El amor sería, entonces, una conciencia piadosa, es decir, la aceptación atenta, propensa a ser anunciada, de nuestra relación con el otro, con lo Otro, sobre la que podremos reconocernos afectivamente; y en ello ser libres, personas.

\section{La conciencia amorosa}

Para abordar la pertinencia fundante del amor en el ánimo de la subjetividad occidental y su importancia en la elaboración consciente de la afectividad y de la realidad, la pensadora española se acerca al pensamiento de Agustín de Hipona. Uno de los proyectos del pensamiento agustino había sido conciliar la filosofía antigua con la fe de una nueva religión que se presentaba -según Zambrano- como un impulso ineludible para la vida. ${ }^{41}$ Ahora bien, si para la filosofia antigua lo importante era que el hombre alcanzara una comprensión intelectual, una unidad de idea, que lo desviara de su apego por las cosas mundanas, en san Agustín se trataba de encontrar aquello que en lo más profundo de la intimidad, en las raíces de la propia voluntad, se mantenía invariablemente a pesar de los transitorios apegos mundanos, como la unidad misma del ser. Si para la filosofía platónica alcanzar la verdad era la meta de un intelecto que, en busca de la objetividad, se bastaba a sí mismo mientras participara del anhelo por esa verdad, y que preparaba al pensador para aceptar la muerte al ofrecerle la inmortalidad de las ideas; con san Agustín se trataba de reconocer, de encontrar en sí y amarla, la presencia íntima de lo trascendente al mismo pensamiento que como una verdad superior, le permite al humano mantenerse firme en esta vida siempre tan perturbadora. ${ }^{42} \mathrm{La}$ intencionalidad agustina seguía muy de cerca de la intencionalidad idealista de la filosofía antigua, pero amplificando la pertinencia de la afectividad.

41 Es importante señalar aquí la comparación que hace Zambrano sobre el apego por la vida de la cultura griega y la visión cristiana. En La agonía de Europa, escribe: "El griego no tuvo vocación para la vida; la tuvo para la razón, para la belleza, para cosas que sólo alcanzarían su ser en un lugar que no es la vida ni la muerte, sino la inmortalidad. Y por ello descubrieron la inmortalidad, que en ellos tiene más claridad y forma que en parte alguna. (...) Dicho está que la esperanza, para los griegos, residía en la razón, en el camino abierto por la razón, y que a ella se agarraron en el camino de salvación que fue la filosofía." (Trotta, Madrid, 2000, pp. 69-70) "La esperanza cristiana, en cambio es un réplica a otra desesperación: la desesperación que se obstina en vivir y que en medio de las mayores desdichas aún se queja de su ser perecedero. (...) Desesperación que se obstina en vivir, hambre de vivir consumiéndose, no hambre de orden ni de razón. (...) Era la desesperación, la rabia de vivir que esperaba a Cristo, al conciliador, al que habla de traer resurrección y vida eterna." (Ob. cit., pp. 70-71)

42 Escribe la escritora española comentando al santo obispo de Hipona: "San Agustín ha desvanecido el terror del hombre antiguo, desamparado y desfraternizado. Ha deshecho la pesadilla de la existencia, pues que se alegra de haber sido engendrado. (...) La vida se ha hecho posible." Zambrano, M.: La Confesión: género literario. Mondadori, Madrid, 1988, p. 36. 
El pensamiento zambraniano intenta recoger esa unidad buscada por san Agustín Ya no se trataría de re-encontrarse el alma a sí misma bajo la tutela de una idea abstracta sino de reconocerse humildemente, en tanto particular y junto al resto de las cosas del mundo, bajo la tutela de un ser infinito, Dios, en ella residente. Si el alma lograse atender a Dios, la realidad obtendría, entonces, un sentido, y con ella la propia corporeidad. ${ }^{43}$ La culpa de la perdición de un alma no estaría en las apariencias mundanas, como se desprendía del pensamiento neoplatónico, sino en la responsabilidad de la propia alma para asumir sus facultades y su libre albedrío. Toda alma tendría que aprender a ocuparse en aquello que desde sí misma la trasciende, esto es, atender al anuncio del Verbo - simbolizado por la imagen de Cristo, hijo del inefable Dios Padreque ofrece las bendiciones de un amor que ilumina con su plenitud al Espíritu. Hallar a Cristo sería alcanzar la palabra interior que fundamenta todo poder cognoscitivo y abre la fuerza del verdadero amor: llama ardiente otorgadora de una vida más verdadera, más certera. ${ }^{44} \mathrm{El}$ desprendimiento de la vida que Platón le pedía al amor, es concebido por la religión de Agustín como una calidad moral interior para un mejor vivir. No se trataba ahora de hallar la divinidad en el miedo a lo incomprensible ni en la deducción del intelecto, sino de aceptarla como un don, como una gracia, que participa de la misma sensibilidad. La existencia se fortalecería así de la fe, es decir, del ímpetu afectivo por la original y esencial conciliación trascendente de toda vida.

Los distintivos más importantes del pensamiento de san Agustín los encuentra Zambrano en Las Confesiones. La búsqueda de un sentido trascendente aparece en este libro como expresión de un pensamiento comprometido con la propia existencia. El pensamiento se hace, con las confesiones de Agustín, medio para mantener la integridad de la vida íntima, del "hombre interior", y camino para acceder al supremo Bien, allende de toda precisión intelectual. En ellas - piensa Zambrano- se evidencia el intento agustino por hacer del pensamiento parte de la propia vida que, al reconocer lo trascendente en sí mismo, tuvo como consecuencia el primer enunciado del hombre europeo. $\mathrm{Y}$ es que la característica primordial de toda confesión sería la de expresar el tiempo vivido para reconocer la huella de algo que, a pesar de la dispersión sensible, conformaría una unidad de sentido existencial, un centro vital inteligible y comprometido con la afección humana. $45 \mathrm{Al}$ iniciar una confesión

\footnotetext{
${ }^{43}$ La resurrección y la vida eterna prometidas por el Cristianismo eran de cuerpo y alma.

44 Se revelaría así, en la interioridad del alma, el misterio de la Santísima Trinidad. "Porque el alma es, como el Padre; y de su ser engendra la inteligencia de sí misma, como el Hijo, o como el Verbo; y la relación de este ser a su inteligencia es una vida, como el Espíritu Santo. O también: el alma es, ante todo, un pensamiento (mens) de donde brota un conocimiento en que dicho pensamiento se expresa (notitia), y de su relación a este conocimiento surge el amor que se tiene (amor) ¿No es de manera análoga como el Padre se profiere en su Verbo y como uno y otro se aman en el Espíritu Santo?" Gilson, E.: La filosofia en la Edad Media. Editorial Gredos, S. A., Madrid, 1989, p. 124.

45 "La Confesión no es sino un método de que la vida se libre de sus paradojas y llegue a coincidir consigo misma. No es el único, pero sí tal vez el más inmediato, el más directo. Y tal vez no sea sufi-
} 
-enseña san Agustín- el alma reconoce la unidad original hacia donde dirige lo confesado, al "Ser superior al fondo de mí mismo" por el que la realidad ofrecida estaría plenamente justificada. Por el acto confesional, el alma, escondida entre las cosas del mundo, reconoce por su palabra la divinidad interior a quien nada se le puede esconder. Toda confesión implica un hablar de sí mismo, para sí mismo y para los demás, y por esto se hace método para la revelación evidente del Verbo, "para estar en Cristo", y en ello, aprender a obrar a voluntad -esto es, en libertad de palabra y de pensamiento- la Verdad. Cuando aludimos concientemente a nuestro más íntimo padecimiento, cuando logramos nombrarlo, hacerlo noticia para asumir una visión personal y viva ante el dolor del mundo, la presencia amorosa de una verdad abismal -imposible de precisar racionalmente, pero sobre la que nos podemos levantar para la vida- se revela como lo más evidente. "¿Y para qué esto? Para que yo y quien lo leyere pensemos de qué abismo tan profundo hemos de clamar a ti. ¿Y qué cosa más cerca de tus oídos que el corazón que te confiesa y la vida que procede de la fe?"46

En Las Confesiones de san Agustín - lee Zambrano- el alma se concibe como la mediación entre lo eterno verdadero en ella albergado y lo provisional sensible, como un espacio para la transición, pues su condición sería estar siempre abierta a la alteridad: tanto para recibir, reconocer en sí, lo esencial que la trasciende, como para hallar al semejante y darle sentido unitario a lo dado en la exterioridad mundana. Lo particular del alma humana sería el amor como anhelo de trascender en lo Otro, tal como lo había manejado todo el neoplatonismo, pero ese anhelo se cierne ahora sobre sí mismo en tanto manifestación del Espíritu Santo: es sólo dentro del alma donde la fuerza de ese amor puede hallarse. El conocimiento de sí exige, así, un ensanchamiento del alma que, mediante un amor propio, revela una realidad divina, una verdad, que lo trasciende desde su mayor intimidad. "Pero ¿dónde puede estar lo que de sí misma no cabe en ella? ¿Acaso fuera de ella y no en ella? ¿Cómo es, pues, que no se puede abracar?”.47

El alma está ciertamente en sí, pues se dice alma con relación a sí misma; pero como cognoscente, conocida o cognoscible, dice relación a su noticia, y con referencia al amor con que se ama se la dice amable o amada y amante. Y la noticia, aunque se refiera al alma que conoce y es conocida, no obstante, con relación a sí misma se la puede llamar cognoscente y conocida; no puede ser ignorada la noticia por la que se conoce el alma. Y el amor, aunque se refiere a la mente que ama y cuyo es el amor, sin embrago

ciente; no sea sino preparación, método en sentido estricto para algo que venga después, método en que la vida muestre, precisamente al ponerse en movimiento, su figura esencial y su peculiaridad extrema." Zambrano, M. Ob. cit., p. 23.

46 San Agustín: Las Confesiones II 3, 5. (Obras Completas: Tomo I. "Las Confesiones". Biblioteca de Autores Cristianos, Madrid, 2005.)

47 San Agustín: Las Confesiones X 8, 15. Ob. cit. 
es amor para sí con subsistencia propia; pues se ama el amor, y el amor sólo puede ser amado por el amor, es decir, por sí mismo. Y así, cada una de estas tres realidades existe en sí misma.

Y están recíprocamente unas en otra: el alma que ama está en su amor; el amor, en la noticia que ama, y el conocimiento, en el alma que conoce. ${ }^{48}$

No se trata, entonces, de "enamorarse de uno mismo" y caer en la tentación de tomarse a sí y a las propias reflexiones como lo más importante, sino de asumirse consciente y humildemente bajo la tutela de algo que sólo se explica a sí mismo, desde sí mismo, y cuya aceptación otorga un sentido unificado a la mundana dispersión. La interioridad anímica se siente, así, fundada en algo mayor que abarca la vida mortal, la de todos. Al recibir a las Tres Personas -que son un mismo y único Dios- desde la intimidad más radical, el hombre obra en sí la Verdad originaria que lo fundamenta a él y a la realidad, y esto lo sostiene anímicamente. Puede distanciarse, entonces, de su apego a la vivencia temporal y circunstancial, siempre tan perturbadora, para abocarse a la eternidad en él habida, de la que él mismo es parte.

Zambrano da suma importancia al enlace entre la palabra y la mente que para san Agustín era la revelación amorosa del Espíritu Santo. Si para el obispo de Hipona, el amor del alma era un ofrecimiento de la gracia y la misericordia de Dios manifiesta en el Verbo, en Zambrano será, por eso, el motor impulsor de una sabiduría afectiva, pues sólo por su venia se alumbrarían, por la palabra, las oscuridades humanas asumidas piadosamente. Por el amor ofrecido en la palabra se produce el paso de lo confuso a la luz, de lo opaco a la transparencia. Asimismo, el sujeto zambraniano, al igual que el hombre agustino, vive disperso en el mundo y está siempre pulsando por completarse, por llegar a ser. El conocimiento de sí sería, entonces, una actividad constante que, mediante la palabra, anunciaría las implicaciones afectivas de nuestra experiencia de vida; una actividad apegada a lo temporal que deberíamos ir realizando para reencontrarnos en el Eterno. El lugar más certero al que podríamos llegar sería el que alcanzamos cuando entregados a la palpitación constante, a la interioridad pura del alma, cercioramos nuestro principio afectivo, esto es, cuando aprehendemos la pulsación del amor como un don que habita en nuestra más profunda intimidad. ${ }^{49}$ El paralelismo entre san Agustín y Zambrano

\footnotetext{
48 San Agustín: La Trinidad IX 5, 8. (Obras Completas: Tomo V. "Escritos apologéticos $\left(2^{\circ}\right)$ La Trinidad", Biblioteca de Autores Cristianos, Madrid, 1985.)

49 Amar a Dios ha de pasar por amarse a sí mismo y esto implica en san Agustín "ocuparse de sí". Tal actividad es entendida como el despliegue misericordioso de Dios, es decir, como un ardor entrañable en la hondura del ser que su omnipresencia ofrece y que ha de reconocer en el propio hacer. Explica Hannah Arendt: "El Creador está en el hombre sólo en virtud de la memoria del hombre, que le mueve a desear la felicidad y con ella una existencia que dure por siempre. (...) Sólo al remitirse retrospectivamente la existencia mortal a su fuente inmortal encuentra el hombre creado la instancia determinan-
} 
puede entenderse desde la necesaria humildad humana para reconocer voluntariamente su dependencia de lo divino; se trataría de una necesitad existencial íntima que reclama una fuerza fundante de la voluntad, hacedora de la realidad.

Reconoce explícitamente Zambrano lo mucho que le debe al pensamiento agustino, pero una de las intenciones de la razón poética será deshacer el nudo creado por las exigencias morales con las que el Padre de la Iglesia fundó el cristianismo institucional. 50 Para hacerlo, la pensadora española resalta, ante todo, la noción del Yo de san Agustín como un puro y perenne anhelar lo otro, como un yo nunca satisfecho y siempre propenso a perderse, sin disminuir por esto la unidad -como ente existencial- del sujeto enamorado. Si en san Agustín, la llama ardiente reconoce en su originario arder una eternidad prometida e imposible racionalmente de trasgredir, asumiendo así un certero saber afectivo; en Zambrano la sabiduría se da en la experiencia de una ausencia pura, en la humilde conciencia de la anhelante esperanza de la sensibilidad, equiparada a la nostalgia de un origen perdido ya para siempre. ${ }^{51}$ En este sentido, el amor en la pensadora española se hace un arder en la intimidad más plena, sin promesa de un porvenir evidente al pensamiento; lo que habría sería un futuro apenas soñado como aliento de la esperanza. Se trataría sólo de un anhelante presente afectivo. 52

La reflexión amorosa, asumida por el cristianismo de distintas maneras (como puro amor a Dios, o como amor a un ideal que simbolice la virtud), es para Zambrano una posibilidad de concientización del misterio piadoso en la interioridad de la subjetividad planteada desde una moral idealista y esperanzada. Tal tipo de conciencia habría formando en esencia al sujeto occidental y a su realidad. La razón poética no puede de ningún modo obviarla, pero quiere resaltar la posibilidad reflexiva del amor concebido como una fuerza divina en la intimidad del humano

te de su ser". (El concepto de amor en san Agustín. Ediciones Encuentro, Madrid, 2001, p. 76) Al amar a Dios, el hombre obra en sí la Verdad eterna que lo fundamenta y se olvida de sí en tanto viviente temporal y circunstancial. La confesión sería el método para hacerlo.

50 San Agustín, "Nos reveló el interior del hombre donde la Verdad eterna puede habitar-sí, ya sé, San Pablo-, cosa no griega, es decir, habría que distinguir y lo he hecho siempre, ya que en la filosofía griega el hombre es, más que nada, lugar del Logos. Mas sin abismo, sin corazón. Desde la filosofía 'laica', recurrir a él, como he hecho hasta la saciedad, era indispensable. (...) Creó un infierno. Y la cuestión es ir deshaciendo infiernos." Zambrano, M.: Cartas de La Pièce, Ob. cit., p. 31.

51 "Nostalgia y esperanza son dos direcciones que este sentir originario toma en el tiempo, de tal manera que cuando se diferencian es sólo porque el tiempo, el de la conciencia, las ha separado; sin ese tiempo consciente estarían siempre entremezcladas, como lo están a menudo." Zambrano, M.: El hombre y lo divino, Ob. cit., p. 306.

52 El arder puro del amor cristiano como forma de existencia, en la vida y para ella, lo encuentra Zambrano en sus lecturas de la poesía (especialmente en Dante) y de la mística cristiana (san Juan de la Cruz, Miguel de Molinos, entre otros), donde el peligro de determinar y fijar el anhelo, sin dejarlo resplandecer en su mismo anhelar, sería la más temible amenaza de la llama enamorada, contra la que pelearía todo verdadero cristiano. Caso especial merece en sus reflexiones el amor de Eloísa por Abelardo. 
que sustenta y da sentido a toda la vida afectiva, y disminuir, en lo posible, la pertinencia formal del ideal, aunque esté inevitablemente presente.

El pensamiento zambraniano ve en la formalidad intelectual ofrecida por toda idea -aún la más esperanzada - una amenaza para el reconocimiento piadoso de la alteridad, de lo Otro, de lo aún no pensado. Para solventar este escollo, Zambrano tuvo que fortalecer el papel de la reflexión amorosa dentro de la tragedia de la historia, dentro de la misteriosa y turbia temporalidad, donde lo humano transcurre; en la experiencia trágica $-\mathrm{y}$ la historia casi siempre lo es- la otredad se muestra con mayor gravedad. Sí para san Agustín el amor salvaba la vida al darle la esperanza de una unidad ideal asumida con conciencia, para Zambrano esa esperanza amorosa será la solvencia humana en tanto posible apertura afectiva con la alteridad, con lo desconocido, con lo misterioso, con lo aún no presentado a la voluntad consciente donde la persona tiende a encerrarse y que ha sido la raíz de tantos malos entendidos históricos. 53

\section{De la esperanza}

El tiempo y el amor están en los escritos zambranianos como las categorías de la sensibilidad ${ }^{54}$ más prestas a la elaboración de un itinerario vital que permita enlazar las oscuridades vitales con la luminosidad del saber. El amor, en tanto intención esperanzada desplegada en el tiempo, señala siempre alguna dirección a transitar anímicamente. Llegar al ser se hace posible cuando el anhelo amoroso y la voluntad racional saben acompañarse, señaló siempre el pensamiento neoplatónico al que nuestra pensadora hace continuas referencias; la esperanza sería el resultado de ese intencionalidad unificada del ánimo, nunca completada y apenas pretendida. 55

53 "El espacio interior que abrió san Agustín es un nuevo mundo. María valoró eso desde siempre. (...) Pero ella llegó más allá. La narración agustiniana de su propio interior es un recitado (intencionalmente dialógico pero verdaderamente monológico) de sus peripecias exteriores moralizantemente consideradas, (...) una torrentera de remordimientos y de autoacusaciones terribles, que, sin mucho tardar, pasará luego a aplicársela al prójimo hermano. María supo ir más allá de ese hombre 'interior' que sabe tantas cosas de sí mismo y de los demás. 'La fuente que mana y corre' está más honda que el hombre interior agustiniano. Está antes; y no está en sus manos. Fue especialmente lúcido quitar a san Agustín de manos de san Agustín. Que se rinda, pero no ya al Dios que tiene dentro y habla con ese su interior, sino al que tiene más adentro aún, a aquel en cuyas meras y originarias manos está y es mejor que esté." Andreu, A: "Anotaciones epilogales a un método o camino". En María Zambrano: Cartas de La Pièce, Ob. cit., p. 356.

54 Las categorías de la sensibilidad en Zambrano serían: el tiempo, el amor, la piedad, el rencor, la envidia, la muerte, las entrañas y la nada. (Ver Moreno Sanz, J.: La razón en la sombra. Antología del pensamiento de María Zambrano. "Introducción". Siruela, Madrid, 1993, pp. XI-XXXVII)

55 "La esperanza se deja ver como todo lo que alienta constantemente en sus desfallecimientos, en sus atonías. El conocimiento que el ser humano tiene de sí mismo proviene de lo negativo: de aquello que siente que le falta o de la falla que lo sostiene. Y así, la esperanza salta visible en la desesperanza, en 
Además, la intimidad -entendida como resultado de una sabiduría personal- se estructura sobre una atención viva a las experiencias afectivas e intelectuales en su continuo sucederse, en su íntima conexión y en sus constantes desencuentros entre los que zozobra la experiencia vital. ${ }^{56}$ Zambrano es fervorosa seguidora de estas ideas.

De Ortega y Gasset, acepta Zambrano el valor de la historia en la formación de la persona. El filósofo maestro proponía que la humanidad estaba a la merced del fluir, de las circunstancias, de la siempre cambiante realidad opositora, por lo que su ser no podía lograrse por las puras ideas del pensamiento; además, la actividad misma del pensar como acción humana, no podía desligarse de la temporalidad donde estuviese siendo cumplida. Tanto el ser humano como el pensamiento están irremediablemente sometidos a las variaciones de la historia, sumergidos bajo la temporalidad. ${ }^{57} \mathrm{La}$ exterioridad, la alteridad -lo que continuamente ha de pensarsesería una parte fundante de lo humano y habría que aprender a recibirla, a tratar adecuadamente con ella. Se es, en la medida como son vividas las circunstancias.

Zambrano intentó seguir la relación hombre-mundo planteada por Ortega; no obstante, su pensamiento no se contentó con el reconocimiento de las causas que justificaban o explicaban las circunstancias, y pronto se apuró en buscar un sentido más esclarecedor para la anhelante sensibilidad que la sola historicidad donde queda sucumbida; quería una razón que le ofreciera un carácter trascendente a la propia temporalidad. Con su razón poética, pretendió abrir una brecha al posible determinismo del pensamiento orteguiano: si hay algún sentido trascendente -tal como anhela la sensibilidad- sólo se revelaría en el padecimiento, esto es, mientras se duele o se goza (en sentido extático) el existir. ${ }^{58}$ De ahí que las importantes cir-

la desesperanza y en la exasperación que advienen por un suceso habido en la intimidad del ser entregado a sí mismo, o encerrado dentro de una situación sin salida. (...) Es en lo negativo donde la esperanza encuentra su campo, su lugar." Zambrano, M.: Los bienaventurados, Siruela, Madrid, 1991, p. 101-102.

56 "Y por mucha que sea la madurez de los tiempos "históricos" y la construcción científica que el hombre haga de su historia, quedará siempre en el fondo del ánimo, en eso que hemos llamado "sentir originario", el sentirse suspendido y flotante, a veces a pique de "naufragio", a merced de la totalidad desconocida que nos mueve." Zambrano, M.: El hombre y lo divino, Ob. cit., p. 105-106.

57 Incluso asegura Don Ortega y Gasset: "El hombre, no tiene naturaleza, lo que tiene es historia; porque historia es el modo de ser de un ente constitutivamente, radicalmente, movilidad y cambio." Ortega y Gasset, J.: Sobre la razón histórica, Alianza Editorial, S. A., Madrid, 1996, p. 121.

58 Señala Ann Bundgaard que el pensamiento de María Zambrano "remite a la urgencia de crear una nueva filosofía racional y poética, que, sin abandonar las circunstancias, llegue "más allá", "más adentro", es decir, "más acá" de la filosofía, pues estaría anclada en la vida del hombre concreto, en el sentir originario de las entrañas, en lo sagrado en última instancia." (Ob. cit., p. 35) Escribe la misma Zambrano: "El problema de la realidad en términos filosóficos no tiene en cuenta sino la realidad despojada de sus significación vital, de su carácter de repuesta a la humana demanda; olvida que el hombre no se dirige a la realidad para conocerla mejor o peor, sino después y a partir de sentirla como una promesa, como una patria de la que en principio todo se espera, donde se cree posible encontrarlo todo; 
cunstancias pasan en Zambrano a un segundo plano; lo valedero para la actitud poética, su sabiduría, estaría más en el reconocimiento del dolor, de una sutileza afectiva, de algún matiz de las esperanzas o de las desesperanzas, las propias de todo amor que encause la vida individual o, incluso, la colectiva.Lo que le daría un valor vital a cualquier circunstancia sería la intencionalidad afectiva con la que nos acercamos intuitivamente al entorno; sin esa original intención no sería posible ninguna indagación sobre el ser y ninguna postulación sobre la realidad. Las circunstancias serían, sin duda, el lugar, el medio, donde el misterio queda siempre manifiesto, y donde la sabiduría puede ser revelada.

El misterio de ese impulso inicial de los afectos - lo que llamamos el amor inefable- será una verdad esencial de herencia platónica que Zambrano no quiso nunca abandonar. Se trataba, sin embargo, de una verdad imposible de aclarar, pues su única certeza estaría en permanecer en el fondo insondable de toda palabra que quiera nombrarla, de toda acción que anhele mostrarla. Existiría, entonces, un misterio originario o fuerza originaria imposible de precisar; algo anterior a la voluntad que alienta los deseos, y que, por ello, se encamina hacia el futuro anunciado por el tiempo. Sería una ausencia misteriosa y siempre propensa a revelarse sin satisfacerse nunca a plenitud (se acabaría la vida); algo que incita, desde siempre, para bien o para mal, la esperanza. Pues "La esperanza es la trascendencia misma de la vida que incesantemente mana y mantiene el ser individual abierto",59 "el modo más adecuado, el arma más eficaz, de tratar con el tiempo".60

Zambrano toma la intencionalidad amorosa del sentir -lo que aquí hemos llamamos esperanza- como el fundamento de la afectividad subjetiva y de las relaciones sensibles. La vida es sentida por Zambrano como una temporalidad donde la esperanza -entendida como un amor que intuye la posible unidad de lo heterogéneo- se despliega, y en ese despliegue el sujeto va procesando su anhelo de ser. El anhelo amoroso, la esperanza, sería la medida de un ritmo vital que daría algún sentido - por ambiguo a la razón que pueda ser- a la implacable durabilidad del tiempo. En la posibilidad real de un posible sentido se arriesgan las relaciones afectivas y la historia. Y "Lo histórico es -afirma Zambrano--, la dimensión por la cual la vida humana es trágica, constitutivamente trágica. Ser persona es rescatar la esperanza venciendo, deshaciendo, la tragedia. La persona, la libertad, ha de afirmarse frente a la historia, receptáculo de la fatalidad."61

como un lugar desconocido también donde toda amenaza puede ser desatada." Zambrano, M. Los bienaventurados, Ob. cit., p. 100.

59 Ibid.

60 Ob. cit., p. 104.

61 Zambrano, M.: El hombre y lo divino, Ob. cit., p. 250. 
Es importante apuntar que el pensamiento zambraniano resalta la direccionalidad anímica que el anhelo amoroso de Platón proponía, mas no reconoce la consecución o la satisfacción completada de ese anhelo, y menos en un imposible mundo ideal. ${ }^{62}$ Por la esperanza ofrecida por el amor, y sólo en ella, la vida encontraría su sentido, fatídico o no - poco importa ahora aquí- pues la manera como lo infinito del amor se hace vida esperanzada determinaría el sentido individual, y esto apuntaría a la posibilidad de alcanzar ser, persona.

Escribe Zambrano:

La esperanza inasible es un puente entre la pasividad, por extrema que sea, y la acción, entre la indiferencia que linda con el aniquilamiento de la persona humana y la plena actualización de su finalidad. Un puente también que atraviesa la corriente del tiempo, según la metáfora de que el tiempo es un río que fluye incesantemente. Mas es un puente también sobre el tiempo pues que al llegar a anularlo casi trasportándonos desde la orilla del pasado al futuro, opera así, ya en esta vida, una especie de resurrección.63

Zambrano apunta hacia la tesis de que una inteligencia amorosa, en tanto conciencia de la alteridad y de la posibilidad esperanzada de sentido, sería la única aptitud mediadora para que los afectos logren, por mediación de la palabra, la anhelada trascendencia. La aproximación piadosa y el amor por la palabra revelado, asegurarían el valor del Yo, asumido aquí como un vacío interior que aspira, que espera, ser llenado. El lugar del Yo, escribe:

Ha de ser tal que permita el correr del tiempo sucesivo, que empuje a la conciencia a generarlo por un movimiento intermitente. Ha de ser tal de no estar sumergido en él, ni tampoco cubierto por la temporalidad, sea del éxtasis de las esperanzas cumplidas o del lleno de la atemporalidad. Ha de ser por tanto, un vacío, un cierto vacío que lo mantenga aislado y a flote sobre ese océano de las vivencias declaradas o a medio declarar, esa masa de vivencias sordas, ese rumor que llamamos psique. Ha de estar sobre ella sin perder contacto con ella, ha de flotar marcando así una especie de estela que es propiamente lo vivido. Sólo son vividas propiamente, de entre todas las vivencias posibles y a medio hacer, aquellas sobre las cuales pasa el Yo; sólo allí las vivencias a medio nacer nacen enteramente. Sólo allí nace la vida, como si la vida humana naciera solamente del contacto del Yo con la psique; sólo allí se humaniza la vida, el resto es vida, sí, mas no humana, vida cósmica, vegetal o animal.64

\footnotetext{
62 Para el pensamiento de Zambrano la utopía está más cercana al sueño encantador de la sensibilidad que a una idea formal que se desee a toda costa cumplir. Estar consciente de esta diferencia sería una señal de madurez personal.

63 Los bienaventurados, Ob. cit., p. 103-104.

64 Zambrano, M.: Los sueños del tiempo, Ob. cit., p. 109.
} 
Tener conciencia de esta situación y asumirla, ofrecería la libertad para que la persona se fundase a sí misma ante el mundo y en relación con él.

\section{Referencias Bibliográficas}

Agustín, San: Obras Completas: Tomo V. "Escritos apologéticos $\left(2^{\circ}\right)$ La Trinidad", Biblioteca de Autores Cristianos, Madrid, 1985.

Agustín, San: Obras Completas: Tomo I. "Las Confesiones". Biblioteca de Autores Cristianos, Madrid, 2005.

Andreu, A.: "Anotaciones epilogales a un método o camino". En María Zambrano,

Cartas de La Pièce, Pre-Textos-Universidad Politécnica de Valencia, ValenciaEspaña, 2002, pp: 341-373.

ARENDT, H.: El concepto de amor en san Agustín. Ediciones Encuentro, Madrid, 2001.

Aristóteles: Poética, Monte Ávila Editores, Caracas, 1990.

BundgaArd, A.: Más allá de la filosofia, Editorial Trotta S. A. Madrid, 2000.

García B, J. D.: "Clave Hermenéutica". En Platón: Obras Completas,F H E de la U. C. V, Caracas, 1980. Tomo I, pp: 47-80.

Gilson, E.: La filosofía en la Edad Media, Editorial Gredos, S. A., Madrid, 1989.

Hillman, J.: El pensamiento del corazón, Siruela, Madrid, 1999.

JAeger, W.: Paideia, México, F. C. E., 1985.

Moreno S., J.: La razón en la sombra. Antología del pensamiento de María Zambrano, "Introducción", Siruela, Madrid, 1993, pp: XI-XXXVII.

Ortega y Gasset, J.: Sobre la razón histórica, Alianza Editorial, S. A., Madrid, 1996.

Platón: "Eutifron" y "República". En Obras Completas, F. H. E. de la U. C. V, Caracas. 1980. Tomo I, pp: 163-198 y Tomos VII y VIII.

SteINER, G.: La muerte de la tragedia, Monte Ávila Editores, Caracas, 1991.

Zambrano, M.: La Tumba de Antígona, Siglo XXI editores S. A., México, 1967.

Zambrano, M.: El hombre y lo divino, México, F. C. E., 1973.

ZAmBrano, M.: El sueño creador, Turner, Madrid, 1986.

Zambrano, M.: De la Aurora, Ediciones Turner, Madrid, 1986.

Zambrano, M.: La Confesión: género literario. Mondadori, Madrid, 1988,

Zambrano, M.: Para una historia de la piedad, Torre de las palomas, Málaga, 1989.

Zambrano, M.: “Advertencia I". En La España de Galdós, Endymion, Madrid, 1989, pp: 13-17

Zambrano, M.: Notas de un método, Mondadori, Madrid, 1989.

Zambrano, M.: Los bienaventurados, Siruela, Madrid, 1991. 
Zambrano, M.: Filosofía y poesía, F. C. E., México, 1993.

Zambrano, M.: Claros del bosque, Seix Barral, Barcelona, 1993

Zambrano, M.: Pensamiento y poesía en la vida española, Endymion, Madrid, 1996.

Zambrano, M.: Los intelectuales en el drama de España y escritos de la guerra civil, Trotta, Madrid, 1998.

Zambrano, M.: Los sueños y el tiempo, Siruela, Madrid, 1998.

Zambrano, M.: La agonía de Europa, Trotta, Madrid, 2000.

Zambrano, M.: Cartas de La Pièce. Correspondencia con Agustín Andreu, Pre-Textos-Univ. Politécnica de Valencia, Valencia-España, 2002.

Humberto Ortiz Buitrago

Escuela de Artes de la Facultad de Humanidades y Educación.

Universidad Central de Venezuela usarsif50@gmail.com 